\title{
Affectation and Rainfall Contribution of Tropical Cyclones in Puerto Rico from 1980 to $2016^{+}$
}

\author{
José C. Fernández-Alvarez ${ }^{1,2, *}$, Rogert Sorí ${ }^{1,3}$, Albenis Pérez-Alarcón ${ }^{1,2}$, Raquel Nieto ${ }^{1}$ and Luis Gimeno ${ }^{1}$ \\ 1 Environmental Physics Laboratory (EPhysLab), CIM-UVigo, Universidade de Vigo, 32004 Ourense, Spain; \\ rogert.sori@uvigo.es (R.S.); albenis.perez.alarcon@uvigo.es (A.P.-A.); rnieto@uvigo.es (R.N.); \\ l.gimeno@uvigo.es (L.G.) \\ 2 Department of Meteorology, Higher Institute of Technologies and Applied Sciences, University of Havana, \\ La Havana 10400, Cuba \\ 3 Instituto Dom Luiz, Faculdade de Ciências da Universidade de Lisboa, 1749-016 Campo Grande, Portugal \\ * Correspondence: jose.carlos.fernandez.alvarez@uvigo.es \\ + Presented at the 3rd International Electronic Conference on Atmospheric Sciences, 16-30 November 2020; \\ Available online: https://ecas2020.sciforum.net/.
}

Citation: Fernández-Alvarez, J.C.; Sorí, R.; Pérez-Alarcón, A.; Nieto, R.; Gimeno, L. Affectation and Rainfall Contribution of Tropical Cyclones in Puerto Rico from 1980 to 2016. Environ. Sci. Proc. 2021, 4, 30. https://doi.org/10.3390/ecas202008130

Academic Editor: Anthony R. Lupo

Published: 13 November 2020

Publisher's Note: MDPI stays neutral with regard to jurisdictional claims in published maps and institutional affiliations.

Copyright: (C) 2020 by the authors. Licensee MDPI, Basel, Switzerland. This article is an open access article distributed under the terms and conditions of the Creative Commons Attribution (CC BY) license (http://creativecommons.org/licenses /by/4.0/).

\begin{abstract}
This study investigated the number of tropical cyclones (TCs) that affected Puerto Rico during the June-November hurricane season in the period 1980-2016, and their contribution to the total precipitation. Special attention was dedicated to assessing the role of atmospheric-oceanic teleconnections in the formation of TCs that affect this island. The HURDAT2 tropical cyclone climatology database and the multi-source weighted set precipitation (MSWEPv2) data with a spatial resolution of $0.1^{\circ} \times 0.1^{\circ}$ were used. A total of 92 TCs within a $500-\mathrm{km}$ radius of Puerto Rico were identified for the study period. Contrary to what was expected, a similar percentage of affectation was found between those TCs formed under El Niño and La Niña conditions. Regarding the North Atlantic Oscillation, a $23.91 \%$ of the 92 TCs that affected Puerto Rico formed under the negative phase, while the $13.04 \%$ during the positive phase, which is explained in agreement with previous findings with the weakening and shift to the south and west of the Azores High during the negative phase of North Atlantic Oscillation. The role of the Sea Surface Temperature on the genesis of TCs that affected Puerto Rico was also assessed through the Atlantic Meridional Mode and the Atlantic Warm Pool area. It is confirmed that the affectation of TCs in Puerto Rico is highly related to the eastward extension of the Atlantic Warm Pool and the Sea Surface Temperature gradient in the tropical North Atlantic region. Indeed, a northward shift in latitude and longitude in genesis position was found from July to November. Finally, a monthly analysis revealed that in August and September the maximum mean rain contribution from TC was $\sim 17 \%$ for the grid but with values in the $20-30 \%$ interval.
\end{abstract}

Keywords: tropical cyclones; rainfall contribution; teleconnections; Puerto Rico

\section{Introduction}

Tropical cyclones (TCs) are one of the most devastating atmospheric phenomena that develop in the tropics due to strong surface winds, associated tornadoes, and floods caused by their intense rains. Despite this, the rainfall associated with TCs can play a positive role as a source of freshwater, even becoming the most important to increase the level of dams and other surface water deposits [1]. Therefore, TCs are the main weather phenomena in the hydrological cycle for tropical and semi-arid regions around the world [2]. For instance, several studies have shown that TCs contribute to seasonal or annual rainfall depending on the characteristics and evolution of its wind field, topographic effects, atmospheric humidity, and size, but mainly, by the proximity of these systems to the coastline [3-5]. 
Specifically, the percentages of TCs contributing to the accumulated precipitation have been studied by data from different sources. From gridded daily rainfall analysis based on rain gauge observations. Larson et al. [6] found that landfalling TCs show values of 15-20\% for the Mexican coasts and U.S. Golf in the period 1950-1998. Later, Ren et al. [7] using rain gauge data showed that the ratio of TC-precipitation compared to the accumulated total is $20-30 \%$ over China in the period 1971-2004. Using monthly passive microwave rainfall estimates over two oceanic basins, Rodgers et al. $[4,8]$ determined that TCs contribute 7\% (3-4\%) to the North Pacific (North Atlantic) cumulative rainfall. On the other hand, several studies using the Tropical Rainfall Measurement Mission (TRMM) multi-satellite dataset have also been carried out to evaluate TCs- contribution at a global or basin-scale [9-12].

Some studies have indicated that TCs-activity is related to climatic variability controlled by the Atlantic Meridional Mode (AMM) [13] and El Niño-Southern Oscillation (ENSO) [14]. Furthermore, some studies (e.g., [15,16]) suggest that North Atlantic Oscillation (NAO) $[17,18]$ also affects TCs; a negative phase of the NAO is associated with a weaker High Subtropical system that extends further south and favors the westward propagation of TCs toward the eastern North America. It is also known that a strengthening of the Atlantic Warm Pool (AWP) has an impact on the upper-level wind change, reducing in the troposphere the vertical wind shear that favors the formation of hurricanes and their intensification during August-October in the North Atlantic (NATL) basin [19]. Therefore, an important aspect to take into account for investigating the genesis and rainfall contribution of TCs is the possible influence of these modes of climate variability.

The Caribbean region, and particularly Puerto Rico (PR), are affected by TCs during the hurricane season, which occurs from June to November. Some results have also found that hurricane-induced rainfall has reached $300 \mathrm{~mm}$ at several stations located in PR [20] during lat years, therefore, the role of TCs rainfall in the total precipitation over PR is of utmost importance for the hydrological resources of the country. Indeed, it has been studied previously by several authors. Rodgers et al. [8] showed that the greatest contribution of rainfall from TCs is nearly 30\% and occurs over the northeast of PR. According to the findings of Khouakhi et al. [20] a large fraction (20-40\%) are also found along the east coast of the United States, the Gulf of Mexico, and PR.

Hernández and Matyas [21] argue that TCs rainfall variability over PR is related to the following elements: the storm center distance from the island's coast, the environmental moisture distribution, the storm duration, and the horizontal translation speed. In 2017, Hernández and Matyas [22] carried out a more detailed analysis of the spatio-temporal distribution of precipitation from station data interpolated to surfaces by different interpolation methods. They also found that largest rainfall contribution by TCs occur in August and September, representing 20\% and 30\% respectively, while the lowest contributions were found for June and November. In this research, the authors proposed as future research to determine the spatio-temporal changes of the TC rainfall contribution, and therefore assess if climate variability or change has caused a decrease or increase TC rainfall contribution over PR. Therefore, this work aims to quantify the amount of rainfall supplied by TCs using a long-term gridded precipitation dataset, and to investigate the role of oceanic and atmospheric teleconnection on the variability of the TCs affectation and the associated impact of the rainfall contribution.

\section{Study Area}

With an area of around $9000 \mathrm{~km}^{2}$, Puerto Rico is the main island of the same name, and the smallest island of the Greater Antilles archipelago, located in the Caribbean Sea [23]. The orography is varied as a function of the island's complex and varied geology [24], highlighting the coastal plains and the central mountain range, as observed in Figure 1. The climate is humid tropical, with a narrow range of daily temperature because of its location in the tropics and the buffering effect of the surrounded waters of the Atlantic 
Ocean [25]; and the average annual temperature is $26^{\circ}$ centigrade [23]. According to Torres-Valcárcel et al. [26], the dry season occurs from December to April, while the wet season from May to November. The island experiences a significant variation concerning the spatial and temporal distribution of rainfall and runoff resulting from it. Thus, the geographic pattern presents a contrast between the north coast, with about 70 inches of annual rainfall, and the south coast, with about 35 inches of annual rainfall [27]. Indeed, the hydrographic network is very dense, but the largest is found in the northern part of the country (see Figure 1).

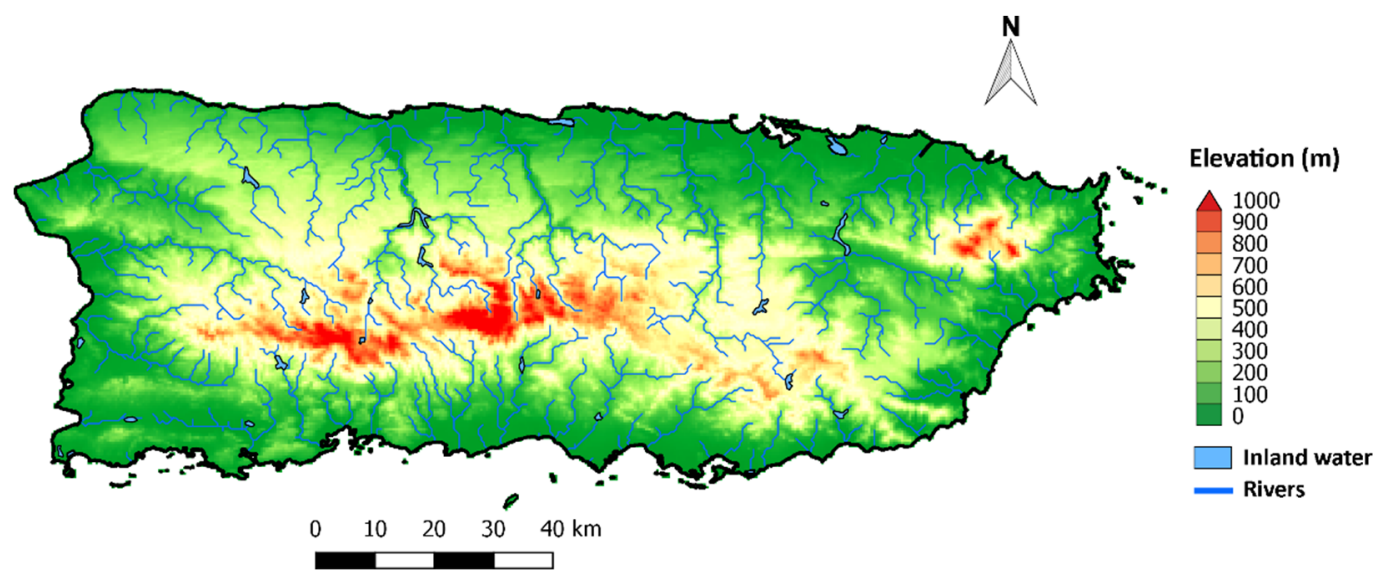

Figure 1. The geographical extension of Puerto Rico. The elevation is shaded in green-brown (in meters above sea level) from the HydroSHEDS project [28] and the river and inland water shaded in bluish colors.

\section{Material and Methods}

\subsection{Datasets}

To determine the number of TCs that affected Puerto Rico in the period 1980-2016, the Atlantic hurricane database (HURDAT2) was used. This dataset provides the location, maximum wind, and minimum central pressure of all known tropical, and subtropical cyclones every six hours [29] and it is freely available at [30]2. The precipitation from the Multi-Source Weighted-Ensemble Precipitation (MSWEP) v2 [31] on a regular latitude/longitude grid of $0.1^{\circ} \times 0.1^{\circ}$ and temporal three hourly resolutions, for the period 1980-2016 were also used. This database performed an optimal merging of a wide range of data from different sources. MSWEP v2 data are freely available upon request at http://www.gloh2o.org/ (accesed on 10 July 2020).

To assess the relationship between atmospheric and oceanic teleconnections and the number of TCs that affected PR during the period of study, we considered the ENSO, $\mathrm{NAO}$, and AMM indices. These modes of variability are known to induce large-scale control of tropical Atlantic cyclonic activity [32,33]. The classification of months under the positive (El Niño) and the negative (La Niña) phase of ENSO, freely provided at https://psl.noaa.gov/people/cathy.smith/best/ (accessed on 10 July 2020) was used. The values of the NAO index were obtained through the Climate Prediction Center (CPC) at https://www.cpc.ncep.noaa.gov/products/precip/CWlink/pna/nao.shtml (accessed on 10 July 2020). The monthly climate time series of the AMM index were downloaded from https://psl.noaa.gov/ (accessed on 10 July 2020). To determine the negative, neutral, and positive phases of the NAO and AMM was used the same approach of Patricola et al. [34] and Muñoz and Rodrigo [35]. The phase of the phenomenon is positive (negative) when the index value is greater (less) than the standard deviation of the series determined for the study period.

The AWP area was calculated for every month from June to November for the period 1980-2016. The monthly values of Sea Surface Temperature (SST) with a horizontal resolution of $1^{\circ}$ in longitude and latitude from the COBE-SST dataset [36] were used. This 
dataset is freely provided by the NOAA/OAR/ESRL PSL, from their web site at https://psl.noaa.gov/ (accessed on 10 July 2020).

\subsection{Methodology}

We considered that a TC affected PR if in its trajectory the center of the system was located $500 \mathrm{~km}$ or less away from the coast. This criterion takes into account the TC primary wind circulation region ( $80-400 \mathrm{~km}$ radius from the TC center), and the range of the curved TC cloud shield (550-600 km radius) [37]. Various studies have also implemented a radius of $\sim 500 \mathrm{~km}$ with the same aim for regions such as México [38], Central and North America [38], and China [39]. However, the use of a $500 \mathrm{~km}$ radius can influence the inclusion of the precipitation associated with troughs in the total accumulated.

To investigate the relationship between the genesis of TCs that affected PR, and different modes of climate variability were accounted the TCs formed during each phase of the ENSO, NAO, and AMM during the period of study. A composite analysis was performed to quantify the average TC rainfall contribution during months under the positive, neutral, and negative phases of these modes. The same analysis was performed for larger, small, and neutral AWP. Those seasons when the AWP occupied more (less) than $25 \%$ of its climatological area $\left(\sim 4.4 \times 106 \mathrm{~km}^{2}\right)$ were considered larger (smaller) AWPs, otherwise has been considered neutral [40].

\section{Results and Discussion}

\subsection{TC Activity during Hurricane Season in the Period 1980-2016}

In the study period of 1980-2016, 564 TCs were formed in the NATL basin, and of these only 92 TCs affected PR directly or indirectly. Figure 2a shows the interannual variability of the number of TCs for 1980-2016. Blue bars represent the total number of TCs, and red bars the amount of TCs that affected the island according to the criterion here used. The mean affectation $(\sim 16 \%)$ is represented by the solid green line. The maximum number of affectations occurred during the very active cyclonic season of 2008 followed by 2005 and 1995. Figure $2 \mathrm{~b}$ also shows that most of the TCs that have influenced the weather conditions in PR corresponds to TCs whose center moves at a distance of $500 \mathrm{~km}$, because only in six seasons $(1984,1989,1996,1998,2004$, and 2011) at least 1 TC landfall for PR was identified.

The trajectories of TCs that affected PR are shown in Figure 3a, while the location of the genesis of the 92 TCs that affected PR is are shown in Figure 3b. The analysis revealed that in June there has been no impact of any TC to PR from 1980 to 2018. For the rest of the months, the genesis of TCs occurred along the tropical NATL from the coast of West Africa to the Caribbean Sea. Although in October and November mostly occurred to the west between the $49^{\circ} \mathrm{W}$ and $70^{\circ} \mathrm{W}$. Each marker represents a specific month where it is observed that from July to November there is a northward shift in latitude and longitude of the TC genesis areas as shown in Figure 3c, where the mean genesis positions are zoomed. In particular, there is a marked difference from July to November and a very similar behavior in August and September. 

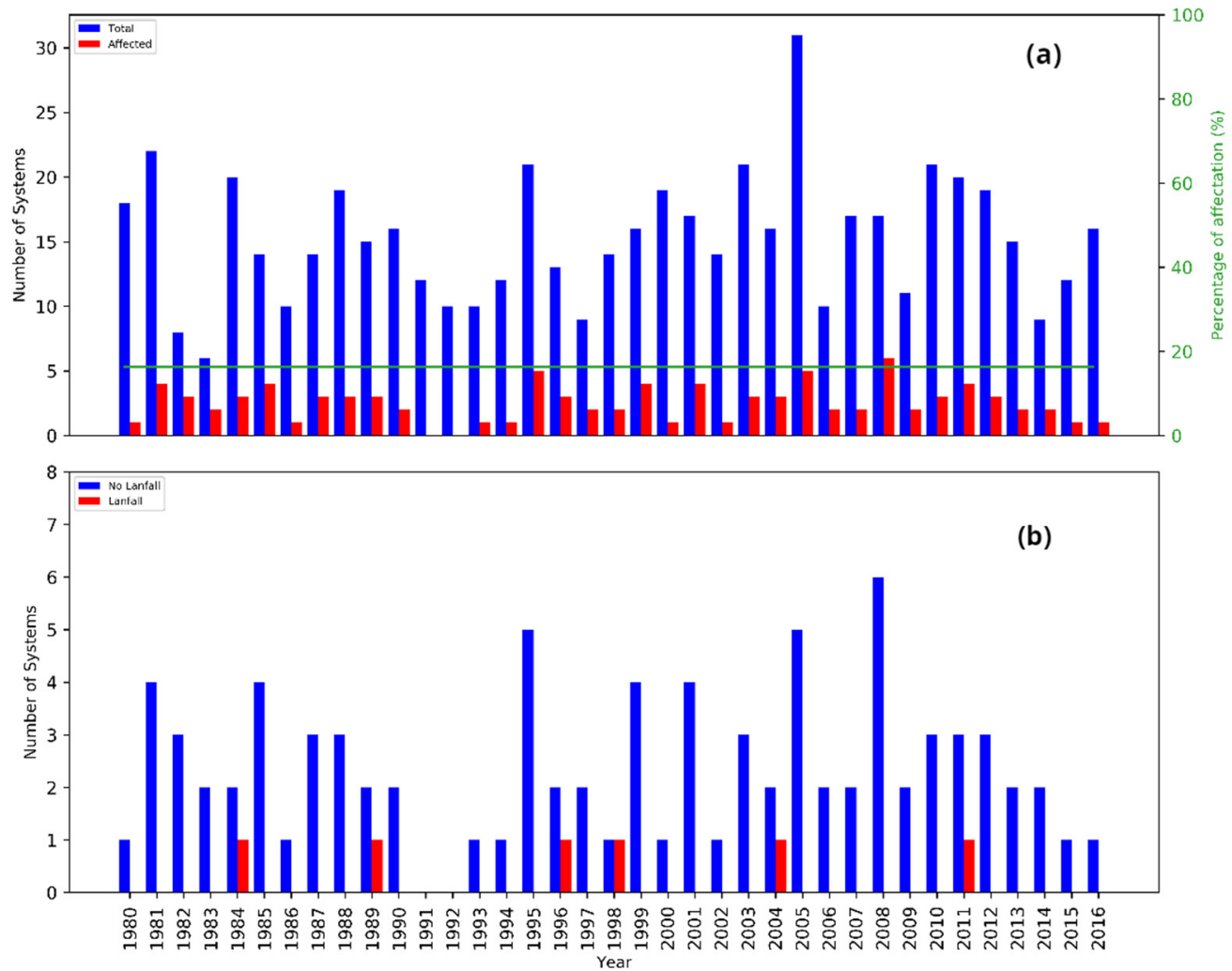

Figure 2. (a) Number of TCs formed in the NATL basin (blue bars) and TCs affectation (red bars) to PR, the solid green line shows the mean affectation; (b) TCs-landfall over PR (red bars) and TCs-no landfall (blue bars) that affected PR. Period June-November of 1980-2018.

Relationship between the TC Activity and the ENSO, NAO, AMM, and the AWP

Figure $4 \mathrm{a}, \mathrm{c}$ illustrates the interannual variability of the number of TCs that affected PR formed during each ENSO and NAO phases. It can be observed that in years with the maximum number of affectations by TCs (e.g., 1981, 1985, 1995, 1999, 2001, 2005, 2008, and 2011) prevailed the neutral and negative phases of ENSO. A similar result was found for the NAO, although, there were some TCs formed under the positive phase of the NAO. The above suggests that the cyclonic activity and the affectation to PR are active in the presence of neutral and negative ENSO and NAO phases. Figure $4 \mathrm{~b}, \mathrm{~d}$ resume as percentages the genesis of TCs that affected PR under the ENSO and NAO phases for the entire period of study. The results show no differences in the formation of TCs between the positive and negative phases of ENSO, $17.39 \%$ formed under Niño and Niña conditions (Figure 4a). Regarding the NAO, Figure 4a shows that apart from the neutral conditions, the negative phase favored the formation of a greater number of TCs $(23.91 \%$ of the total) than the positive phase (13.04\% of the total); confirming the importance of the Azores High position on the TCs genesis in the NATL basin. 


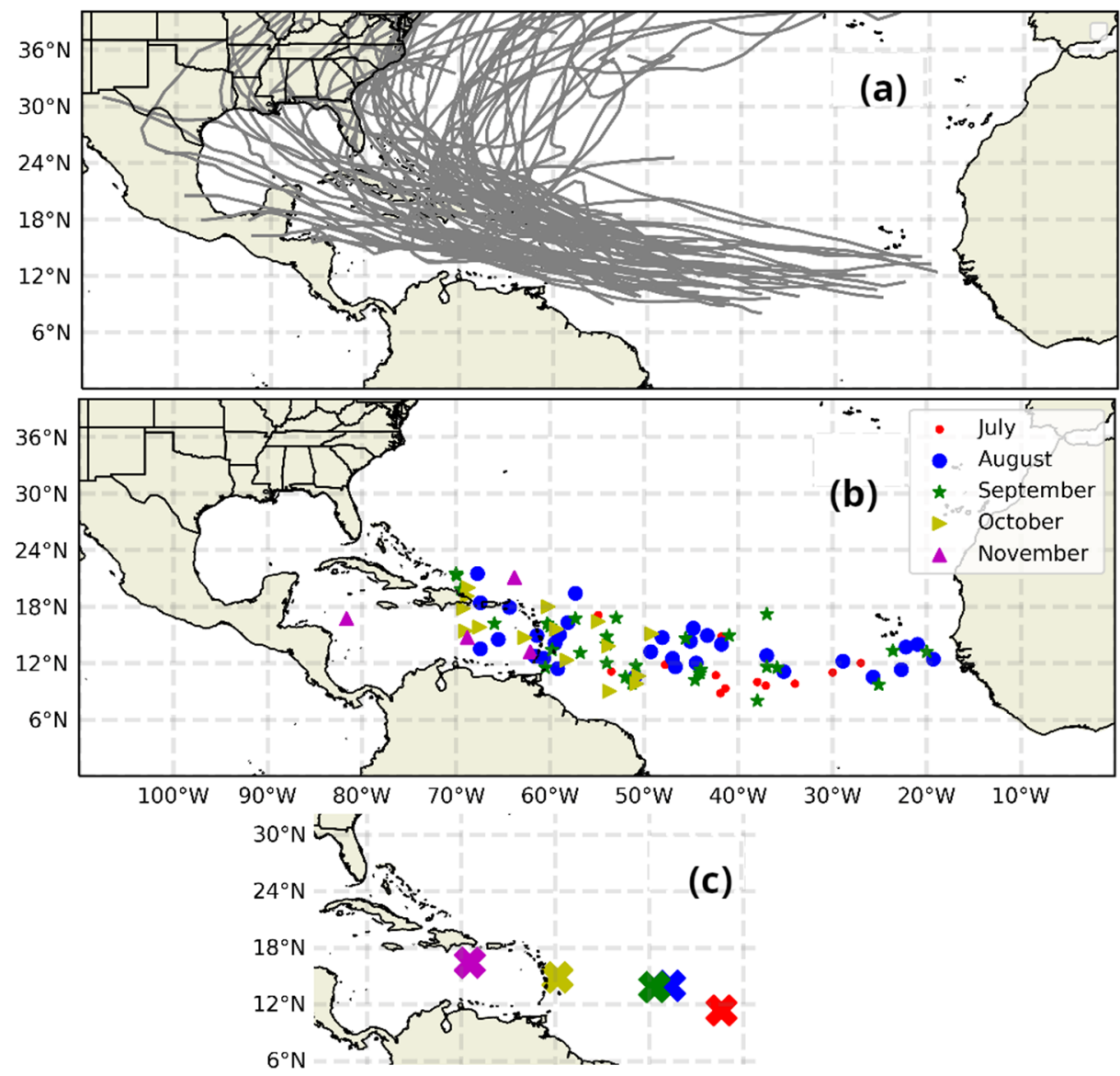

Figure 3. (a) Tracks of TCs that affected PR; (b) Areas of the genesis of TCs for the months of July November; (c) Zoom of the mean position of genesis for each month.


Figure 4. Left column: Number of TC systems during the different phases of ENSO (a) and NAO (c). Right column: Percentage of the number of TCs during each phase of ENSO (b), NAO (d). Period: 1980-2016. 
According to Lim et al. [30], the cyclonic activity can be modulated by a combined impact of various modes of climatic variability, particularly those involving the SST. Therefore, a similar analysis was carried out for the AMM and AWP. The results of the interannual behavior for the AMM and AWP are shown in Figure 5a,c. The AMM showed a marked predominance of the neutral phase with $\sim 73 \%$ followed by the positive phase $\sim 23.91 \%$ and $3.26 \%$ for the negative phase (see Figure $5 b$ ). This was much accentuated in the years of the maximum number of TCs. For AWP there was mostly a predominance of smaller AWP in the 1980-1990s, but prevailed larger AWPs in the rest of the seasons. These results are summarized in Figure $5 \mathrm{~d}$. The percentage values for larger AWP, neutral AWP and smaller AWP were $61.96 \%, 21.74 \%$, and $16.3 \%$ respectively.
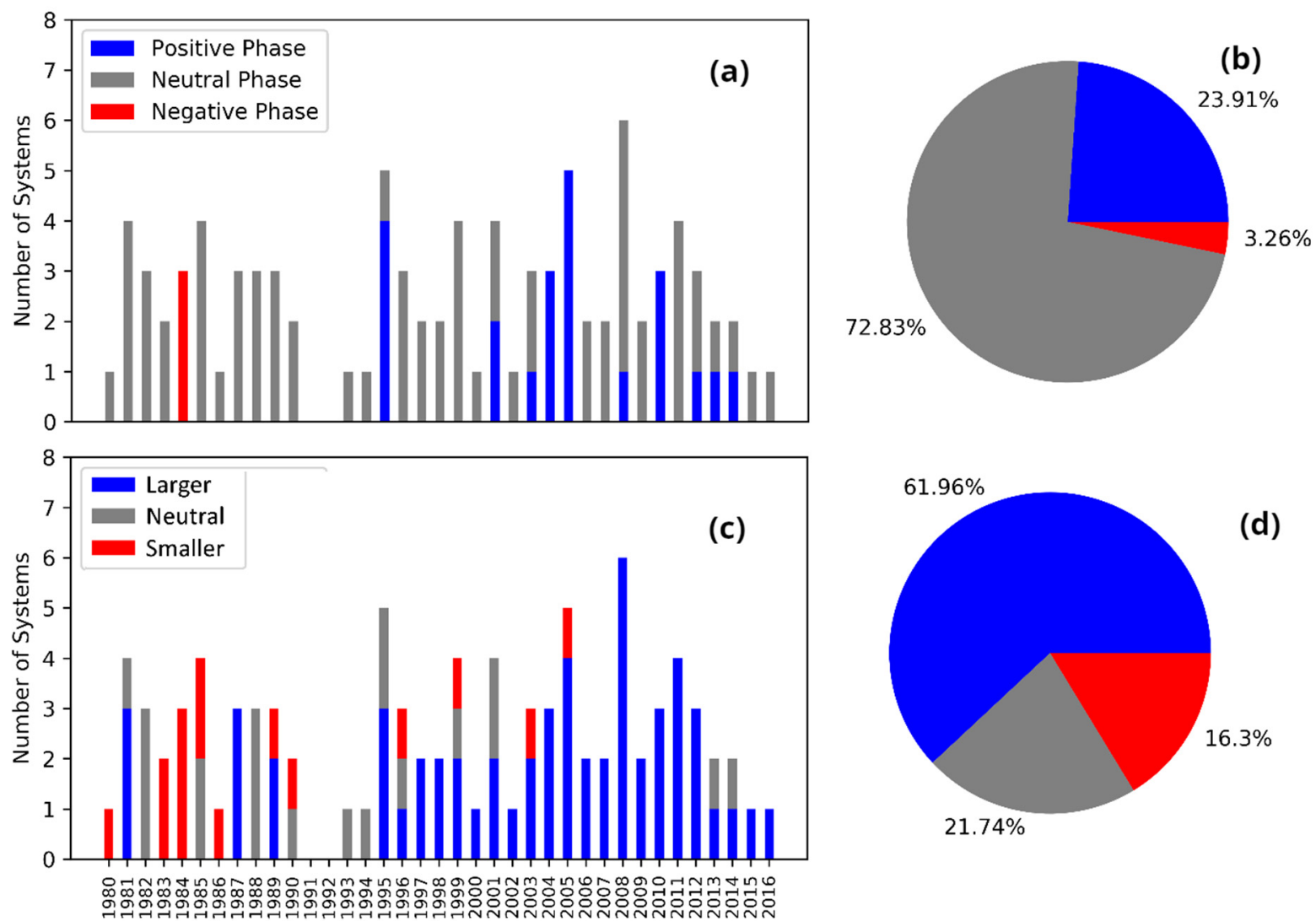

Figure 5. Left column: Number of TC systems during the different phases of AMM (a) and AWP (c). Right column: Percentage of the number of TCs during each phase of AMM (b), AWP (d). Period: 1980-2016.

\subsection{Monthly Mean TCs Rainfall and Their Contribution to Puerto Rico}

The monthly mean total rainfall, the monthly mean TCs rainfall, and its percentage respect the total monthly rainfall over PR was calculated and represented in Figure 6. These patterns highlight because of the little spatial variability, which may be associated with the resolution of the data. June had peculiar characteristics since the contribution was null since there was no TC affectation according to the criterion here used. However, it is remarkable that the accumulated rainfall for this month ranged from $45 \mathrm{~mm}$ to 250 $\mathrm{mm}$, with maximum values toward the northwest and east of the island (Figure 6a). On the contrary, the lower mean rainfall values in this month are observed on the South coast. As for July, a similar pattern is shown in Figure 6d, with a maximum marked on the east and west of the island. The precipitation ranges were from $45 \mathrm{~mm}$ to $250 \mathrm{~mm}$, as shown in Figure 6d. This month occupied the third place with the least number of TCs affectations to PR, with 13 . The mean TCs rainfall pattern shows a southwest-northeast change from 0 up to $5 \mathrm{~mm}$ respectively, revealing a major rainfall contribution over the eastern half of PR but the lowest accumulated precipitation associated with TCs during 
the cyclonic season (Figure 6e). This may be associated with the formation of few TCs in the central Atlantic Ocean during the hurricane season [41].
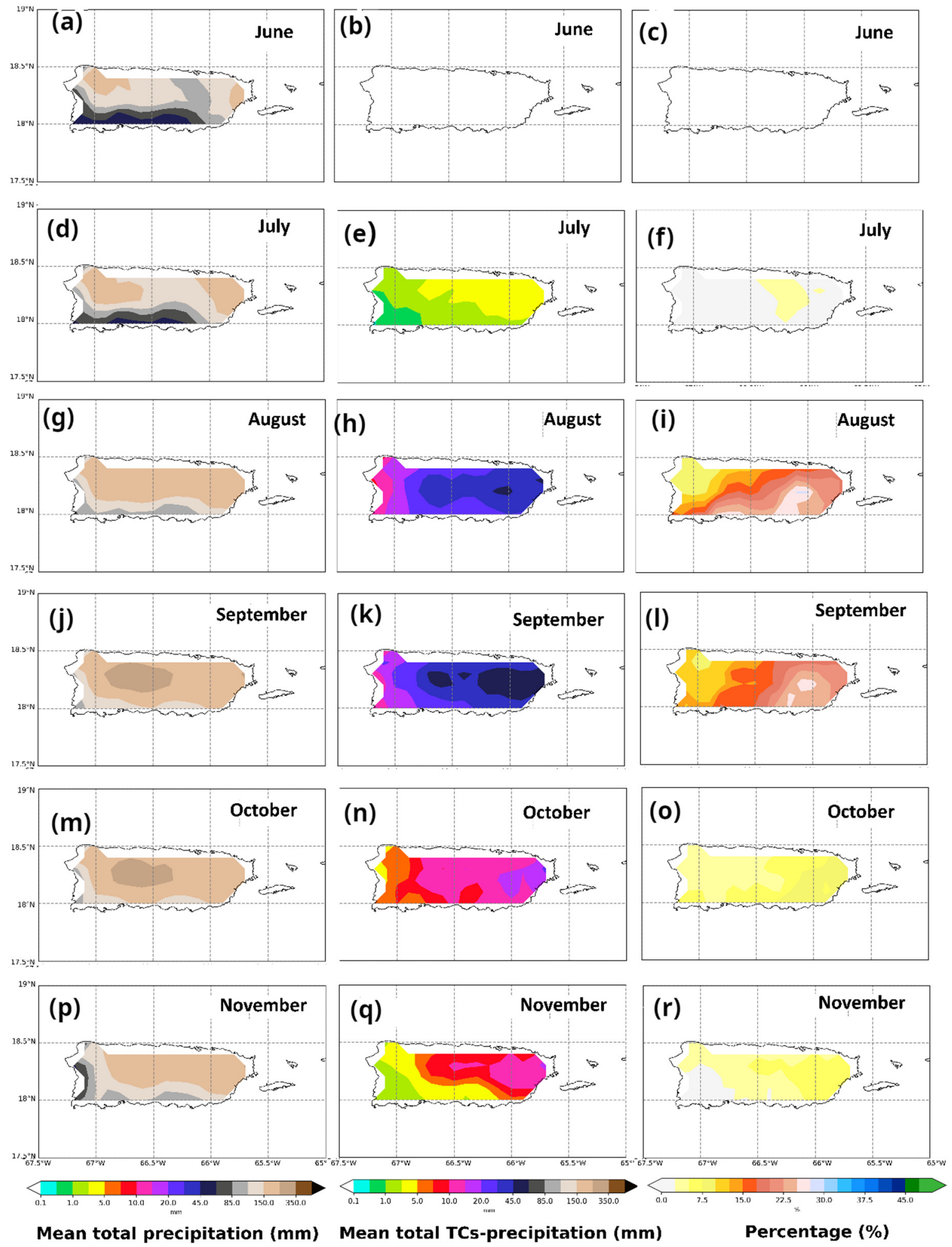

Figure 6. Mean total precipitation $(\mathbf{a}, \mathbf{d}, \mathbf{g}, \mathbf{j}, \mathbf{m}, \mathbf{p})$, Mean total TCs-precipitation $(\mathbf{b}, \mathbf{e}, \mathbf{h}, \mathbf{k}, \mathbf{n}, \mathbf{q})$ and its percentage $(\mathbf{c}, \mathbf{f}, \mathbf{i}, \mathbf{l}, \mathbf{o}, \mathbf{r})$ for June, July, August, September, October, and November. Period 1980-2016.

In August the mean rainfall pattern reveals great homogeneity for the entire island, but lower precipitation occurs over the south of the island (Figure $6 \mathrm{~g}$ ), a drier area than 
the north since it is the leeward zone of the central mountain range of PR [42]. During the period of study, in August, PR received the highest number of affectations from TCs (31 systems). The TC rainfall contribution in August varied from maximum values ( 45 $\mathrm{mm})$ in the east to lower mean rainfall in the west $(\sim 10 \mathrm{~mm})$ (Figure $6 \mathrm{~h})$. Consequently, these patterns expressed in percentage respect the mean total rainfall reveal that TCs provide between the $5 \%$ in the northwest of the island to $15-30 \%$ in the southeast. This result is similar to that achieved by Rodgers et al. [8], Khouakhi et al. [20], and Hernández and Matyas [22]. In September and October the maximum precipitation occurs over the center and west of PR (>250 mm) (Figure 6j,m). In September PR was affected by 29 TCs, which left the largest rainfall in the eastern of the country (Figure 6k).

The intensity of the rainfall pattern associated with TCs decreases toward the west from $65 \mathrm{~mm}$ to $10 \mathrm{~mm}$ approximately, revealing a similar pattern to that obtained for August (Figure 6h). The TCs rainfall contribution for September expressed in percentage appear in Figure 6i, and reveals that the highest contribution ( 27.5\%) occurs in the eastern half of the island. In October, PR was affected by fewer TCs (15) that contribute to the total precipitation over PR (Figure 6n). The contribution expressed in percentages reveals a pattern with lower compared to the previous 2 months $(<10 \%)$ (Figure 6o), since the TCs rainfall ranged in intervals of 3-20 $\mathrm{mm}$. With very similar rainfall patterns (Figure 6j,m), September and October are the rainiest months of the hurricane season [43], but there were notable intensity differences in terms of the TC rainfall contribution, being less for October because the precipitation for this month is due to multiple processes that include localized convective thunderstorms, west-to-east moving troughs and cold fronts [44]. Finally, in November the rainfall pattern clearly shows lower values over the southern and west of PR (Figure 6p). A similar pattern is observed in the mean total TCs rainfall (Figure 6q), and revealing lower contributions than in previous months. Only 4 TCs affected PR in November during the period of study. The pattern of TCs rainfall contribution expressed as a percentage of the mean total of the month also describes a decrease from the east to the west of the island and a maximum of $\sim 12.5 \%$.

The patterns of TCs rainfall and its contribution to the total rainfall plotted in Figure 6 revealed its maximum values toward the half east of the island. This behavior may be associated with the predominance of the northwest and northward trajectories of TCs before reaching the longitude of Puerto Rico. Figure 7 shows the probability density function (PDF) determined using Gaussian kernels [45]. The maximum probability area appears to the east of $\mathrm{PR}$, and extends from approximately $15-20^{\circ} \mathrm{N}$ and $60-75^{\circ} \mathrm{W}$, which means that a major number of TCs had trajectories through this area. A circle radius of $\sim 500 \mathrm{~km}\left(4.5^{\circ}\right)$ centered on a latitude and longitude of Puerto Rico permits to observe that a great part of the high probability area lies within the circle. On the other hand, there is a secondary maximum to the south of the island, but it is negligible compared to the global maximum mentioned above.

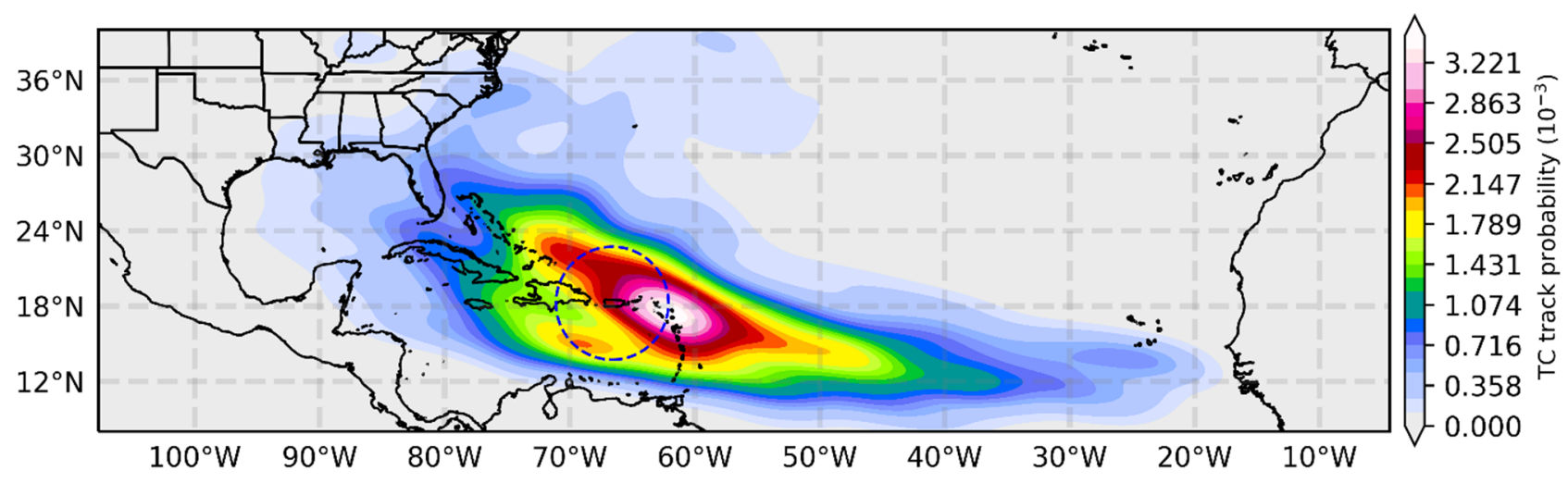

Figure 7. The probability density function (PDF) for TCs tracks. The blue circle represents a distance equal to approximately $500 \mathrm{~km}\left(\sim 4.5^{\circ}\right)$. 


\section{Conclusions}

In this study, the number of TCs that affected Puerto Rico during the hurricane season of the period 1980-2016 was determined, and was quantified their contribution to the total precipitation. The results reveal that Puerto Rico was affected by 92 TCs directly or indirectly, which represents the $16 \%$ of the total number of TCs formed in the NATL basin, approximately three TCs per season. The TCs rainfall contribution for every month of the hurricane season except for June was calculated, since this month no TC affected PR. It reveals that the half east of Puerto Rico tends to receive the major amount of rainfall associated with TCs, which is greater in August and September, representing between the 5 and $30 \%$ of the total average climatological rainfall of these months across the island. This is associated with the highest probability density of TCs trajectories observed over the Atlantic Ocean near to the east of the country. Another analysis revealed that approximately the same number of TCs that affected Puerto Rico was formed under El Niño and La Niña conditions. Regarding the NAO, the results revealed that $23.91 \%$ of the total number of TCs that affected RP were formed during its negative phase, while $13.04 \%$ were formed in the positive phase. This result confirms the importance of the weakening and the shift of the Azores High on the genesis of TCs. The SST in the tropical NATL also showed, as expected, a direct relationship with the genesis of TCs. During the positive (negative) phase of the AMM were formed the $23.91 \%$ (3.26\%) of the TCs that later affected Puerto Rico. Likewise, under larger AWP, neutral AWP, and smaller AWP were formed the $61.96 \%, 21.74 \%$, and $16.3 \%$ of the TCs respectively. Thus, the affectation of TCs in Puerto Rico is highly related to the eastward extension of the AWP and the SST gradient in the tropical North Atlantic region. Finally, the year-on-year contribution was correlated with the number of TCs, showing a positive value of $~ 0.6$, which is above the $95 \%$ significance level. The trend analysis of the contribution and number of systems showed positive values but they were not statistically significant for the period 1980-2016. For future studies, we intend to use observed data for better representing the rainfall spatial variability and evaluate the MSWEP data.

Author Contributions: J.C.F.-A., R.S., R.N., and L.G. conceived the idea of the study. J.C.F.-A., R.S., and A.P.-A. Processed the data and created the figures. J.C.F.-A. and R.S. analyzed the results and wrote the manuscript. All authors analyzed the results and revised the manuscript. All authors have read and agreed to the published version of the manuscript.

Funding: This research was funded by the Spanish Government through the LAGRIMA project (RTI2018-095772-B-I00). This work also received partial support from the Xunta de Galicia under the Project ED431C 2017/64-GRC Programa de Consolidación e Estructuración de Unidades de Investigación Competitivas (Grupos de Referencia Competitiva) and Consellería de Educación e Ordenación Universitaria. Previous funders received cofounding from the ERDF, in the agenda of the Operational Program Galicia 2014-2020.

Institutional Review Board Statement: Not applicable.

Informed Consent Statement: Not applicable.

Data Availability Statement: Hurdat data was obtained from https://www.nhc.noaa.gov/data/\#hurdat. The MSWEP v2 database at http://www.gloh2o.org/. The ENSO, NAO and AMM indices of the following pages https://psl.noaa.gov/people/cathy.smith/best/, https://www.cpc.ncep.noaa.gov/ products/precip/CWlink/pna/nao.shtml, https://psl.noaa.gov/, respectively. Finally, the SST data was downloaded from https://psl.noaa.gov/.

Acknowledgments: J.C.F.-A., R.S. acknowledge the support from the Xunta de Galicia (Galician Regional Government) under the grants no. ED481A-2020/193 and ED481B 2019/070, respectively. A.P.-A. acknowledges a Ph.D. grant from the University of Vigo. All the authors gratefully thank the Princeton Climate Laboratory for freely providing the MSWEP dataset.

Conflicts of Interest: The authors declare no conflict of interest. 


\section{References}

1. Aguilar, B.I. Los Servicios del Agua en el Norte de México en Gestión, Manejo Financiero y Aspectos Ambientales, 1st ed.; Water Utilities: Mexico, NA, USA, 2011.

2. Trenberth, K.E.; Fasullo, J. Water and energy budgets of hurricanes and implications for climate change. J. Geophys. Res. 2007, 112, D23107, doi:10.1029/2006JD008304.

3. Cerveny, R.S.; Newman, L.E. Climatological relationship between tropical cyclones and rainfall. Mon. Weather Rev. 2000, 128, 3329-3336, doi:10.1175/1520-0493(2000)128<3329:CRBTCA>2.0.CO;2.

4. Rogers, E.B.; Adler, R.F.; Pierce, H.F. Contribution to the North Pacific climatological rainfall as observed from satellites. J. Appl. Meteorol. 2000, 39, 1648-1678.

5. Jiang, H.; Zipser, E.J. Contribution to the global precipitation from eight seasons of TRMM data: Regional, seasonal and interannual variations. J. Clim. 2010, 23, 1526-1543, doi:10.1175/2009JCLI3303.1.

6. Larson, J.; Zhou, Y.; Higgins, R.W. Characteristics of landfalling tropical cyclones in the United States and Mexico: Climatology and interannual variability. J. Clim. 2005, 18, 1247-1262.

7. Ren, F.; Wu, G.; Dong, W.; Wang, X.; Wang, Y.; Ai, W.; Li, W. Changes in tropical cyclone precipitation over China. Geophys. Res. Lett. 2006, 33, L20702, doi:10.1029/2006GL027951.

8. Rodgers, E.B.; Adler, R.F.; Pierce, H.F. Contribution of tropical cyclones to the North Atlantic climatological rainfall as observed from satellites. J. Appl. Meteorol. 2001, 40, 1785-1800.

9. Lau, K.M.; Zhou, Y.P.; Wu, H.T. Have tropical cyclones been feeding more extreme rainfall? J. Geophys. Res. Atmos. 2008, 113, doi:10.1029/2008JD009963.

10. Prat, O.P.; Nelson, B.R. Mapping the world's tropical cyclone rainfall contribution over land using the TRMM Multi-Satellite Precipitation Analysis. Water Resour. Res. 2013, 49, 7236-7254.

11. Prat, O.P.; Nelson, B.R. On the link between tropical cyclones and daily rainfall extremes derived from global satellite observations. J. Clim. 2016, 29, 6127-6135.

12. Bagtasa, G. Contribution of tropical cyclones to rainfall in the Philippines. J. Clim. 2017, 30, 3621-3633.

13. Chiang, J.C.H.; Vimont, D.J. Analogous meridional modes of atmosphere-ocean variability in the tropical Pacific and tropical Atlantic. J. Clim. 2004, 17, 4143-4158, doi:10.1175/JCLI4953.1.

14. Colbert, A.J.; Soden, B.J. Climatological variations in North Atlantic tropical cyclone tracks. J. Clim. 2012, 25, 657-673, doi:10.1175/JCLI-D-11-00034.1.

15. Kossin, J.P.; Camargo, S.J.; Sitkowski, M. Climate modulation of North Atlantic hurricane tracks. J. Clim. 2010, 23, 3057-3076, doi:10.1175/2010JCLI3497.1.

16. Elsner, J.B. Tracking hurricanes. Bull. Am. Meteor. Soc. 2003, 84, 353-356, doi:10.1175/BAMS-84-3-353.

17. Wallace, J.M.; Gutzler, D.S. Teleconnections in the geopotential height field during the Northern Hemisphere winter. Mon. Weather Rev. 1981, 109, 784-812.

18. Barnston, A.G.; Livezey, R.E. Classification, seasonality and persistence of low-frequency atmospheric circulation pattern. Mon. Weather Rev. 1987, 115, 1083-1126.

19. Wang, C.; Lee, S.K. Atlantic warm pool, Caribbean low-level jet, and their potential impact on Atlantic hurricanes. Geophys. Res. Lett. 2007, 34, L02703, doi:10.1029/2006GL028579.

20. Khouakhi, A.; Villarini, G.; Vecchi, G.A. Contribution of tropical cyclones to rainfall at the global scale. J. Clim. 2017, 30, 359372.

21. Hernández, J.J.A.; Matyas, C.J. Tropical cyclone rainfall over Puerto Rico and its relations to environmental and storm specific factors. Int. J. Climatol. 2016, 36, 2223-2237, doi:10.1002/joc.4490.

22. Hernández, J.J.A.; Matyas, C.J. Spatial distribution of tropical cyclone rainfall and its contribution to the climatology of Puerto Rico. Phys. Geographys. 2017, 39, 1-20, doi:10.1080/02723646.2017.1354416.

23. Portal Oficial del Estado Libre Asociado de Puerto Rico. Gobierno de Puerto Rico. Available online: http://www.gobierno.pr/GPRPortal/Inicio/InformacionGeneralYTurismo/Geografia/Geografia.htm (accessed on 19 September 2020).

24. Renken, R.A.; Ward, W.C.; Gill, I.P.; Gómez-Gómez, F.; Rodríguez-Martínez, J. Geology and Hydrogeology of the Caribbean Islands Aquifer System of the Commonwealth of Puerto Rico and the U.S. Virgin Islands. Regional Aquifer-System Analysis-Caribbean Islands; U.S. Geological Survey Professional Paper 1419; US Geological Survey: Sunrise Valley Drive Reston, VA, USA, 2002, doi:10.3133/pp1419.

25. Murphy, S.F.; Stallard, R.F. Water quality and mass transport in four watersheds in Eastern Puerto Rico. In Water Quality and Landscape Processes of Four Watersheds in Eastern Puerto Rico: U.S. Geological Survey Professional Paper 1789; Murphy, S.F., Stallard, R.F., Eds.; USGS: Reston, VA, USA, 2012; 292p.

26. Torres-Valcárcel, Á.; Harbor, J.; González-Avilés, C.; Torres-Valcárcel, A. Impacts of Urban Development on Precipitation in the Tropical Maritime Climate of Puerto Rico. Climate 2014, 2, 47-77.

27. PIRA-PR (Plan Integral de Recursos de Aguas de Puerto Rico). Declaración de Impacto Ambiental Estratégica Actualizada; Departamento de Recursos Naturales y Ambientales San Juan: Puerto Rico, Mayo, 2007. 
28. Lehner, B.; Reidy, C.L.; Revenga, C.; Vörösmarty, C.; Fekete, B., Crouzet, P.; Döll, P.; Endejan, M.; Frenken, K.; Magome, J. et al. High-resolution mapping of the world's reservoirs and dams for sustainable river-flow management. Front. Ecol. Environ. 2011, 9, 494-502, doi:10.1890/100125.

29. Landsea, C.W.; Franklin, J.L. Atlantic Hurricane Database Uncertainty and Presentation of a New Database Format. Mon. Weather Rev. 2013, 141, 3576-3592.

30. Atlantic Hurricane Database (HURDAT2) 1851-2019. Available online: https://www.nhc.noaa.gov/data/\#hurdat (accessed on 10 July 2020).

31. Beck, H.E.; Wood, E.F.; Pan, M.; Fisher, C.K.; Miralles, D.G.; van Dijk, A.I.J.M.; McVicar, T.R.; Adler, R.F. MSWEP V2 Global 3Hourly $0.1^{\circ}$ Precipitation: Methodology and Quantitative Assessment. Bull. Am. Meteorol. Soc. 2019, 100, 473-500, doi:10.1175/BAMS-D-17-0138.1.

32. Lim, Y.K.; Schubert, S.D.; Reale, O.; Molod, A.M.; Suarez, M.J.; Auer, B.M. Large-Scale Controls on Atlantic Tropical Cyclone Activity on Seasonal Time Scales. J. Clim. 2016, 29, 6727-67494, doi:10.1175/JCLI-D-16-0098.1.

33. Xie, L.; Yan, T.; Pietrafesa, L.J.; Morrison, J.M.; Karl, T. Climatology and Interannual Variability of North Atlantic Hurricane Tracks. J. Clim. 2005, 18, 5370-5381, doi:10.1175/JCLI3560.1.

34. Patricola, C.M.; Saravanan, R.; Chang, P. The impact of the El Niño-Southern Oscillation and Atlantic meridional mode on seasonal Atlantic tropical cyclone activity. J. Clim. 2014, 27, 5311-5328, doi:10.1175/JCLI-D-13-00687.1.

35. Muñoz, D.D.; Rodrigo, F.S. Effects of the North Atlantic Oscillation on the probability for climatic categories of local monthly rainfall in southern Spain. Int. J. Climatol. 2003, 23, 381-397.

36. Japan Meteorological Agency. Characteristics of Global Sea Surface Temperature Analysis Data (COBE-SST) for Climate Use; Monthly Report on Climate System Separated Volume 12; Japan Meteorological Agency: Tokyo, Japan, 2006.

37. Englehart, P.J.; Douglas, A.V. The role of eastern North Pacific tropical storms in the rainfall climatology of western Mexico. Int. J. Climatol. 2001, 21, 1357-1370, doi:10.1002/joc.637.

38. Dominguez, C.; Magaña, V. The Role of Tropical Cyclones in Precipitation Over the Tropical and Subtropical North America. Front. Earth Sci. 2018, 6, 19, doi:10.3389/feart.2018.00019.

39. Zhang, W.; Vecchi, G.A.; Murakami, H.; Villarini, G.; Delworth, T.L.; Yang, X.; Jia, L. Dominant role of atlantic multidecadal oscillation in the recent decadal changes in Western North Pacific tropical cyclone activity. Geophys. Res. Lett. 2018, 45, $354-362$.

40. Wang, C.; Enfield, D.B.; Lee, S.; Landsea, C.W. Influences of the Atlantic Warm Pool on Western Hemisphere Summer Rainfall and Atlantic Hurricanes. J. Clim. 2006, 19, 3011-3028, doi:10.1175/JCLI3770.1.

41. Elsner, J.B.; Kara, A.B. Hurricanes of the North Atlantic: Climate and Society; Oxford University Press: Oxford, UK, 1999.

42. Calvesbert, R.J. Climate of Puerto Rico and the U.S. Virgin Islands; U.S. Department of Commerce, Climatography of the U.S.; US Department of Commerce: Washington, DC, USA, 1970; pp. 52-60.

43. Picó, R. The Geography of Puerto Rico; Aldine Publishing: Chicago, IL, USA, 1974.

44. Colón, J.A. Climatología de Puerto Rico; University of Puerto Rico Press: Río Piedras, PR, USA, 2009.

45. Turlach, B.A. Bandwidth Selection in Kernel Density Estimation: A Review. In CORE and Institut de Statistique; CiteSeerX: University Park, PA, USA, 1993; Volume 19, pp. 1-33. 